\title{
Intratendinous Ganglion of the Extensor Digitorum Tendon
}

\section{Chan Kwon, Sang Hun Cho, Seung Chul Rhee, Su Rak Eo}

Department of Plastic and Reconstructive Surgery, Graduate School of Medicine,

Dongguk University, Ilsan, Korea

Received: September 23, 2014

Revised: December 8, 2014

Accepted: December 10, 2014

Correspondence to: Su Rak Eo

Plastic and Reconstructive Surgery, DongGuk

University Medical Center, DongGuk University Graduate School of Medicine, 27 Dongguk-ro, Ilsandong-gu, Goyang 410-773, Korea

TEL: +82-31-961-7330

FAX: +82-31-961-7347

E-mail: surakeo@yahoo.com
This is an Open Access article distributed under the terms of the Creative Commons Attribution Non-Commercial License (http://creativecommons.org/ licenses/bync/3.0/) which permits unrestricted noncommercial use, distribution, and reproduction in any medium, provided the original work is properly cited.

\begin{abstract}
Ganglion cyst is the most common benign tumor arising from the hand and wrist. Rarely, they are found within the tendon. To date, only 10 cases in English papers and 7 cases in domestic papers on ganglion cysts in extensor digitorum tendons have been reported. Due to the rarity of this entity, it is difficult to suspect intratendinous ganglion fully based on the physical examination. Accordingly, preoperative studies such as ultrasonography, magnetic resonance imaging are recommended when suspicious result is revealed on the physical examination. Treatment should include en bloc resection of the affected tendon to reduce recurrence. But functional loss always has to be considered. This study reports two cases of intratendinous ganglion cysts that arised from the second and fourth extensor digitorum tendon.
\end{abstract}

Keywords: Ganglions, Tendons, Extensor, Hand

\section{INTRODUCTION}

Ganglion cysts are the most common soft-tissue tumors of the hand. They are rarely found in specific anatomic structures such as the nerve, bone, and tendon. Intratendinous form of ganglion cyst is occasionally found in the hand. Only 10 cases in English papers and 7 cases in domestic papers on ganglion cysts in extensor digitorum tendons have been reported since its introduction in $1985^{1-7}$. This study reports 2 cases of intratendinous ganglion cysts arising from the second and fourth extensor digitorum tendons and discusses general features and surgical plans for this entity.

\section{CASE REPORT}

A 59-year-old male truck driver complained of a six-month history of an enlarging, palpable mass over the dorsum of his right hand. He had no history of other trauma, infection, or inflammation of the hand. A physical examination revealed a mildly tender, approximately $1 \times 1 \mathrm{~cm}$ in sized mass. The mass moved with active excursion of the affected 
tendon. Mild paresthesia was found though there was no pain and Tinel sign. Based on these findings, a ganglion or schwannoma was suspected, and a surgical exploration was performed. A cystic structure measuring $9 \times 6 \times 4 \mathrm{~mm}$ was found in the second extensor digitorum tendon (Fig. 1A, B), and tenosynovitis was observed around the impinged tendon. Tenosynovectomy was performed and the nodule was excised en bloc with a portion of the tendon. The partly ruptured tendon was repaired primarily using 4-0 nylon with interrupted suture technique. Histopathology of the resected ganglion shows a thickened collagenous wall (arrow) containing mucoid substance (asterisk) (Fig. 1C). Three weeks after the surgery, splint was taken off and the patient was allowed to do normal activities. Active finger range of motion was normal six months after the surgery.

A 7-year-old male presented a 1-year history of an enlarging, non-tender mass over the dorsum of his right hand. There was no significant history associated with the mass.
During the physical examination, the mass moved with the active excursion of the fourth extensor digitorum tendon. Intraoperatively a cystic mass measuring $20 \times 3 \times 3 \mathrm{~mm}$ was found on the radial side of the fourth extensor digitorum tendon (Fig. 2A-C). The lesion had no connections to the joint capsule of tendon sheath. Slight tenosynovectomy was preceded and the mass was extirpated from the tendon and this made minimal tendon defect. No tendon repair was accompanied because the defect was not large to affect continuity of the tendon or cause any weakness. Pathology revealed cystic mass with a thin, smoothly lined membrane around the tendinous tissue suggesting the diagnosis of an intratendinous ganglion (Fig. 2D). Splint was not applied because immobilization was not necessary. The patient was discharged on the day of surgery and recovered uneventfully with the normal function of the affected hand 2 years after the surgery.
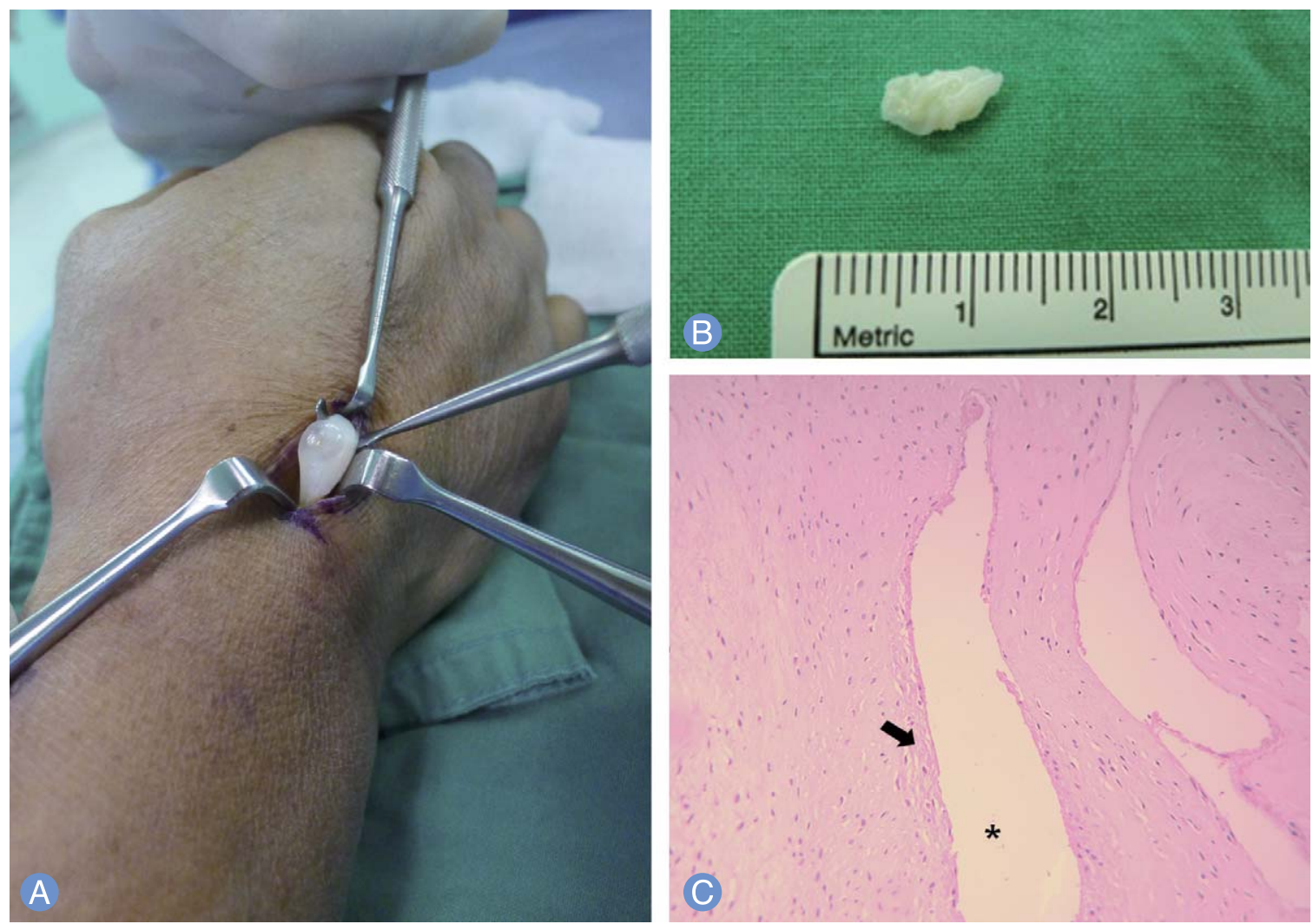

Fig. 1. (A) A ganglion in the second extensor digitorum tendon. (B) An excised ganglion and portion of the tendon. (C) Pathologic findings of resected ganglion. The specimen shows a thickened collagenous wall (arrow) containing mucoid substance (asterisk) (H\&E, $\times 20)$. 

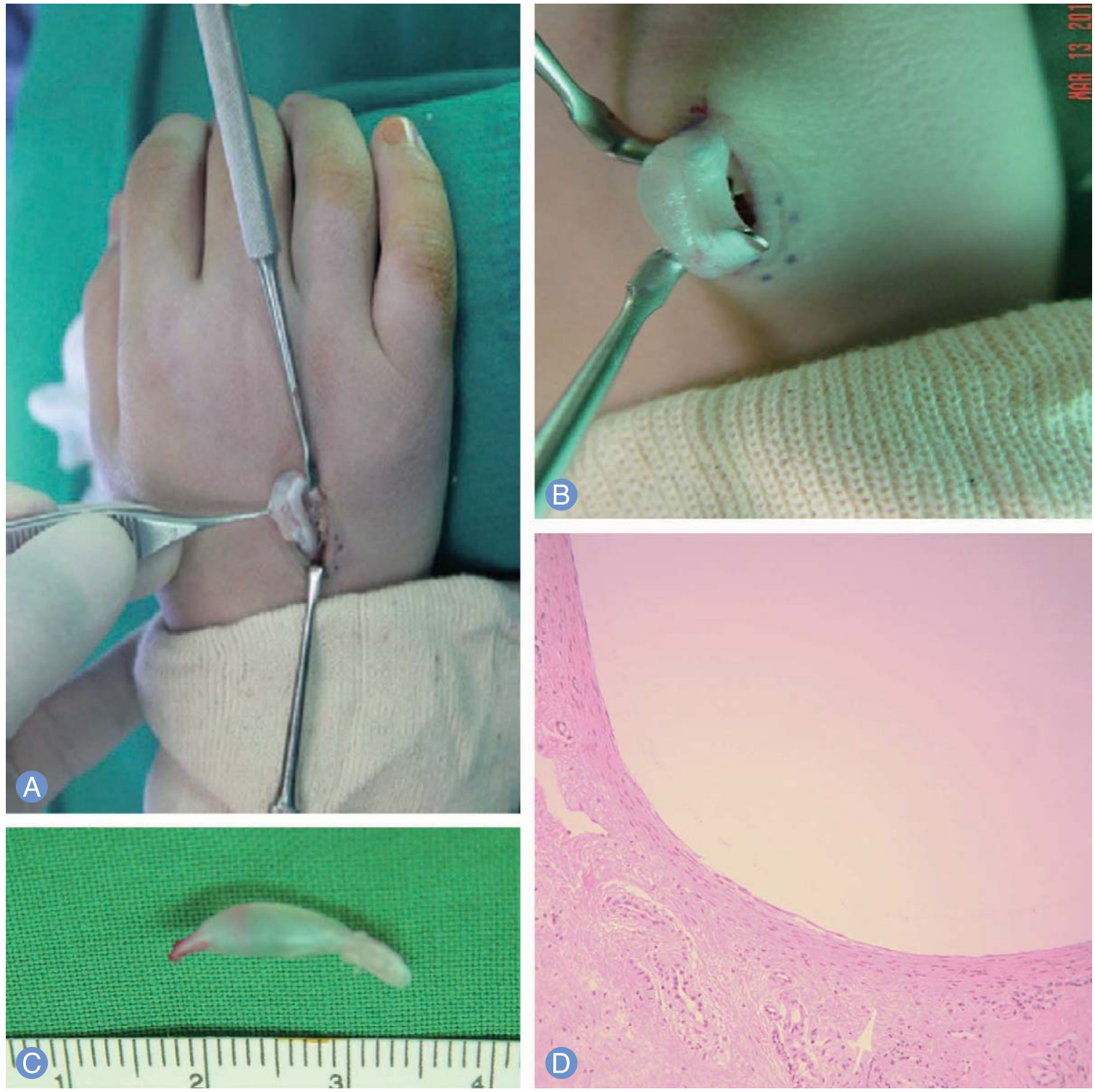

Fig. 2. (A, B) ganglion in the fourth extensor digitorum tendon. (C) An excised fusiform ganglion. (D) A histologic examination reveals characteristic fibrous tissue wall without a synovial lining $(\mathrm{H \& E}, \times 20)$.

\section{DISCUSSION}

Intratendinous ganglion is an intrasubstance lesion confined by the tendon's margins, sheath or paratenon. Because of the rarity of this entity, it is difficult to suspect an intratendinous ganglion solely by a physical examination. Most of tumors, scar, tenosynovitis of an infectious or inflammatory origin can be included in the differential diagnosis. Accordingly, preoperative studies such as ultrasonography (US) and magnetic resonance imaging (MRI) can be helpful when a suspicious result such as concurrent move- ment of the mass and the affected tendon is revealed during the physical examination ${ }^{8}$. MRI and US are highly sensitive, specific modality for delineating the nature of cysts, including their size, location and relationship to the surrounding structures though they were not tried in this case. Between these two, MRI provides a better anatomical overview of the surrounding bony and soft tissue. MRI signal characteristics of intratendinous ganglion are typical of other ganglions, depicting homogenous, low signal intensity on T1-weighted images and a high signal intensity on T2-weighted images. Thin peripheral wall enhancement is seen after gadolinum 
injection. Since intratendinous ganglion originates within the tendon substance it typically has no connection to the tendon sheath or joint capsule?

Although the etiology of intratendinous ganglion is uncertain, repetitive injury to the tendon with subsequent cystic degeneration is considered to be a possible cause because associated tendon tears or tenosynovitis is often present around the lesion ${ }^{10}$. We also observed inflammatory sign of the synovium surrounding the affected tendon and this advocates the fact that intratendinous ganglion arises secondary to the tenosynovitis as previous studies have stated. Furthermore, this suggests that early detection is important because subsequent surgical resection can control the inflammation and prevent unnecessary procedures.

As with other types of ganglions, observation can be an acceptable treatment in some cases. However, we recommend surgical excision since the function of the affected tendon may be progressively weakened by the ganglion. Objective symptoms such as pain, interference with activity, overlying skin change have been considered to be surgical indications of the intratendinous ganglion. However, as our cases, doubt about the diagnosis and even an aesthetic purpose might be included as indications. Surgical procedure includes longitudinal excision of the ganglion in the tendon and repair of the affected tendon with nonabsorbable suture. Although En bloc resection of the tendon can reduce the risk of recurrence, functional loss always has to be considered. If tenorrhaphy alone is not sufficient, tendon graft or transfer can be considered ${ }^{11}$. In this study, partly injured tendon was repaired with interrupted suture in one case, and there was no functional disability by the two-year follow-up.

An intratendinous ganglion should be considered in the differential diagnosis of a soft tissue tumor in the hand.
During preoperative examination, it is important to check whether the tumor is mobile with the tendon and the function of the involved tendon.

\section{REFERENCES}

1. Young SC, Freiberg A. A case of an intratendinous ganglion. J Hand Surg Am. 1985;10:723-4.

2. Ikeda $\mathrm{K}$, Tomita $\mathrm{K}$, Matsumoto $\mathrm{H}$. Intratendinous ganglion in the extensor tendon of a finger: a case report. J Orthop Surg (Hong Kong). 2001;9:63-5.

3. Lee SU, Kim HM, Yoo JM, Kim J, Roh YT, Park IJ. intratendinous ganglion in the extensor digitorum communis of the hand: a case report. J Korean Soc Surg Hand. 2010;15:47-51.

4. Lee JH, Jung SN, Kwon H. clinical experience of intratendinous ganglion in the extensor tendon of hand. J Korean Soc Plast Reconstr Surg. 2005;32:259-61.

5. Kang YK, Ha NK, Lee JY, Song ES, Rhee SK. Intratendinous ganglion in the extensor tendon of a finger: a case report \& MRI findings. Korean Soc Surg Hand. 2003;8:182-5.

6 Jung DH, Han JS, Lee YG, Ok KA, Han SH. Ganglion in extensor tendon of the hand-case report. J Korean Orthop Assoc. 1995;30:170-2.

7. Cho DY, Suh JG, Yang SB, Koh ES. Intratendinous ganglion: a case report. J Korean Orthop Assoc. 1990;25: 1786-9.

8. Kim SK, Park JM, Choi JE, Rhee SK, Shim SI. Intratendinous ganglion cyst of the semimembranosus tendon. Br J Radiol. 2010;83:e79-82.

9. Kishimoto K, Akisue T, Fujimoto T, et al. Intra-tendinous ganglion in the long head of the biceps humeri. Skeletal Radiol. 2008;37:263-5.

10. Seidman GD, Margles SW. Intratendinous ganglia of the hand. J Hand Surg Am. 1993;18:707-10. 


\section{지신건에 발생한 건내결절종}

\section{권찬 · 조상헌 · 이승철 · 어수락}

동국대학교 일산병원 성형외과

결절종은 수부에서 가장 흔하게 발생하는 종양이다. 드물게 건 내에 발생하기도 하는데 현재까지 지신건에서 발생한 결 절종은 전세계적으로 총 10 건 만이 보고되었다. 발생 빈도가 낮은 이 질환을 이학적 검사만으로 감별하기는 어렵기 때 문에 검진상 건내 결절종이 의심되는 경우 초음파나 자기공명영상 같은 추가적인 검사를 시행하는 것이 좋다. 치료는 재발 방지를 위해 침범된 일괄 절제하는 것이 좋으나 기능적인 손실을 항상 염두 해야 한다. 저자들은 2,4 번째 지신건 에 발생한 건내 결절종 2 예를 보고하는 바이다.

색인단어: 결절종, 건, 신전근, 수부

접수일 2014년 9월 23일 수정일 2014년 12월 8일

게재확정일 2014년 12월 10일

교신저자 어수락

경기도 고양시 일산동구 동국로 27

동국대학교 일산병원 성형외과

TEL 031-961-7330 FAX 031-961-7347

E-mail surakeo@yahoo.com 